\title{
Pagnino, Servet y Arias Montano Avatares de una traducción latina de la Biblia Hebrea *
}

\author{
Natalio FernÁNDEZ MARCos \\ Emilia FERNÁNDEZ TEJERO ** \\ Instituto de Filología - CSIC, Madrid
}

\section{INTRODUCCIÓN}

Los humanistas del siglo XVI tuvieron como meta primordial, a la hora de estudiar el texto bíblico, la vuelta a las fuentes originales: el hebreo para el Antiguo Testamento (AT) y el griego para el Nuevo (NT). Esta actitud desencadenó importantes controversias, entre las que destacamos, por lo que al texto del Antiguo Testamento se refiere: la acusación de «hebraizantes» a quienes defendían la necesidad de conocer y utilizar el texto original hebreo, y las disputas sobre el valor de la Vulgata, traducción del hebreo (AT) y del griego (NT) al latín, realizada por Jerónimo a finales del siglo IV d.C.

La Vulgata fue una traducción innovadora en su tiempo, porque sustituyó a traducciones latinas anteriores, englobadas bajo el término técnico Vetus latina, que habían utilizado como Vorlage el texto griego de Septuaginta. Con el cristianismo ya consolidado en el imperio romano, Jerónimo aprendió hebreo para traducir de nuevo la

\footnotetext{
* En el cuatrocientos cincuenta aniversario de la muerte de Miguel Servet (Ginebra 1553).

**natalio@ filol.csic.es, tejero@ filol.csic.es

Sefarad 63 (2003) págs. 283-329

(c) CSIC

ISSN 037-0894
} 
Biblia al latín, la lengua franca de la época. Esta iniciativa le supuso duros enfrentamientos con Agustín, partidario de las viejas traducciones latinas y más aún de la Septuaginta, versión que consideraba tan inspirada como el texto hebreo mismo ${ }^{1}$.

Con el tiempo, la traducción de Jerónimo se impuso como la Biblia de Occidente, hasta el punto de que, al final de la Edad Media, se convirtió en el texto bíblico oficial de la Iglesia. En el concilio de Trento, en la sesión del 8 de abril de 1546, fue declarada auténtica ${ }^{2}$. El texto de la Vulgata de Jerónimo había fundamentado la teología, la filosofía, y el derecho medievales; cualquier modificación del mismo podría afectar a la concepción religiosa de la época y, en consecuencia, a los principios vitales de la sociedad occidental.

Si la traducción de Jerónimo en el siglo IV llegó a producir motines en el norte de África ${ }^{3}$, no fueron menores los problemas derivados del deseo de los humanistas del XVI por buscar una traducción latina más ajustada al original hebreo. Sanctes Pagnino fue el primer autor que se impuso tan ardua tarea.

\section{LA VERSIÓN DE PAGNINO}

El dominico italiano Sanctes Pagnino (ca. 1470-1536) publicó una versión completa al latín del Antiguo y Nuevo Testamento, distinta de la Vulgata, en Lyon en $1528^{4}$. Fue el primer traductor que introdujo en el texto la división en versículos, por medio de

\footnotetext{
${ }^{1}$ Entre los estudios más recientes, cf. R. GonZÁlez SAlinero, Biblia y polémica antijudia en Jerónimo (Madrid 2003).

2 ... statuit et declarat, ut haec ipsa vetus et vulgata editio... pro authentica habeatur, et quod nemo illam reicere quovis praetextu audeat vel praesumat; $\mathrm{cf}$. $\mathrm{H}$. DENZINGer y P. HünERMANn, El magisterio de la Iglesia (Barcelona 1999) pág. 483.

${ }^{3}$ Cf. N. Fernández Marcos y E. Fernández Tejero, Biblia y Humanismo. Textos, talantes y controversias del siglo XVI español (Madrid 1997) pág. 18.

${ }^{4}$ Utilizamos el ejemplar de la Biblioteca Maruceliana de Florencia (R. e. 13) Para una detallada evaluación de esta Biblia, cf. A. Morisi Guerra, «Santi Pagnini traducteur de la Bible», en Théorie et pratique de l'exégèse, eds. I. BACKus y F. HIGMAN (Ginebra 1990) págs. 191-210.
} 
números colocados al margen. La traducción iba precedida, entre otras cosas, de:

- dos privilegios papales (Adriano VI y Clemente VII);

- dos cartas de Pico de la Mirándola a Pagnino (fechadas en 1518 y 1521$)$

- una carta de Pagnino a Clemente VII;

- un prólogo del autor, que es un elogio de la Escritura, en contraposición con las disquisiciones filosóficas y teológicas de la época (ecos de Erasmo, que también se encuentran en la titulación Instrumenta, que no Testamenta, para la Biblia judía y la Biblia cristiana). Desgraciadamente, no se trata de un prólogo, digamos, científico, en el que se expliquen los criterios seguidos por el autor. Sólo por el trabajo que Arias Montano llevó a cabo más tarde sobre el texto latino de Pagnino puede descubrirse la forma de proceder del dominico ${ }^{5}$.

Al final de su traducción, Pagnino incluyó un índice sobre la interpretación de los nombres hebreos, arameos y griegos contenidos en la Sagrada Escritura.

La traducción es muy literal, pero la impresión resultó poco cuidada, como testimonia una larga lista de castigationes erratorum,

ce qui fut certainement une épine dans le coeur de son auteur. De plus, le texte ne comportait pas les commentaires qui devaient être un instrument absolument nécessaire pour la lecture ${ }^{6}$.

Pagnino había previsto acompañar su traducción de seis volúmenes de notas críticas, como anunció en su carta al Papa Clemente VII, impresa en su edición de $1528^{7}$, pero tales notas nunca fueron publicadas ${ }^{8}$.

\footnotetext{
${ }^{5}$ Nos referimos a la edición de la Biblia hebrea con traducción interlineal de Pagnino, corregida por Arias Montano, publicada en el volumen de Apparatus de la Biblia Regia.

${ }^{6}$ A. Morisi Guerra, Santi Pagnini, pág. 191.

${ }^{7}$ post haec aedemus, et annotationum libros sex in vetus ac novum instrumentum, ut rationem eis redamus, quid, cur mutatum sit, et diversas explicemus interpretationes...

${ }^{8}$ Cf. G. Bedouelle, «L'humanisme et la Bible», en Le temps des Réformes et la Bible, eds. G. Bedouelle y B. Roussel (París 1989) págs. 59-99: pág. 78.
} 
Sí fueron incluidas breves notas marginales en los libros de Génesis y Éxodo, relativas al contenido de algún capítulo o que recogen variantes de grafía en los nombres propios.

La traducción de Pagnino nació en un contexto de desconfianza, por tomar como base el texto hebreo del Antiguo Testamento; creció a la sombra de un hereje, Servet, encargado de su reedición; contó con las críticas de ideologías tan diversas como las de Lutero, Münster y Mariana ${ }^{9}$; mas se salvó del olvido gracias a la tenacidad filológica de Arias Montano, quien, aunque no pudo utilizarla como columna latina de la Políglota de Amberes, por expresa prohibición de Felipe II ${ }^{10}$, sí logró perpetuar el texto de Pagnino para el Antiguo Testamento en el Apparatus de esa Políglota.

La edición de Pagnino fue reeditada por Servet en Lyon, 1542; por Robert Estienne en París, 1557 y 1577 (la traducción del Antiguo Testamento fue corregida según notas de Vatablo, y la del Nuevo Testamento fue reemplazada por la de Teodoro Beza ${ }^{11}$ ), y, como hemos visto, fue incorporada en la Biblia Regia, con traducción aún más literal, obra de Arias Montano.

\section{LA EDICIÓN DE SERVET}

\subsection{Descripción}

Hemos trabajado con la edición de Lyon, 1542, ejemplar de la Biblioteca Nacional de Madrid (R/22276):

\footnotetext{
9 A. Morisi Guerra, «Santi Pagnini», pág. 193: «cette Bible qui, utilisée en plus d'une occasion mais toujours à la limite de toute orthodoxie, n'a jamais été acceptée et accueillie par aucune confession, par aucun groupe chrétien».

${ }^{10}$ Cf. B. Macías Rosendo, La Biblia Políglota de Amberes en la correspondencia de Benito Arias Montano (Ms. Estoc. A 902) (Huelva 1998) pág. 80, y J. BARrientos García, Fray Luis de León. Epistolario. Cartas, licencias, poderes, dictámenes. Edición y estudio por —— (Madrid 2001) págs. 90-92.

${ }^{11}$ Cf. F. Vigouroux, Dictionnaire de la Bible (París 1912) vol. IV (segunda parte), cols. 1949-1950 y W. A. Copinger, The Bible and Its Transmission (Londres 1897) págs. 251-252.
} 
Biblia sacra ex Santis Pagnini tralatione (sic), sed ad hebraicae linguae amussim nouissime ita recognita, et scholiis illustrata, ut plane noua editio uideri possit. Accessit praeterea Liber interpretationum Hebraicorum, Arabicorum, Graecorumque nominum, quae in sacris literis reperiuntur, ordine alphabetico digestus, eodem authore. Lvgdvni, Apud Hvgonem à Porta. M. D. XLII.

En este ejemplar, una nota manuscrita advierte de que:

Esta Biblia esta Correcta y expurgada conforme Al Indice expurgatorio de los señores Inquisidores en este Conuento de S. Francisco de Guadalaxara a 20 de octubre de 1595.

La acompañan firmas de otros censores.

La Biblia comienza con un Prólogo al lector, firmado por Miguel Servet (Michael Villanouanus); le sigue otro Prólogo de Ioannes Nicolaus Victorius, dirigido a los posibles destinatarios de la Sagrada Escritura; finalmente, el Prólogo que escribiera Sanctes Pagnino para su traducción de los dos Testamentos (1528).

A continuación, la edición de Pagnino, según el orden de los libros que presenta la Vulgata, con algunas diferencias:

- la división en versículos que Pagnino había introducido y que había sido objeto de polémica se sustituye por divisiones marginales por párrafos, señalados con las letras mayúsculas del alfabeto latino. Estas letras permitirán la localización de los pasajes en el índice final de nombres propios (Liber interpretationum Hebraicorum, Arabicorum, Graecorumque nominum);

- cada capítulo va provisto de un encabezamiento (ausente en la edición de Pagnino) en el que se resume el contenido del mismo y, ocasionalmente, se sugieren conexiones tipológicas con personajes y acontecimientos del Nuevo Testamento;

- se incluyen numerosas notas marginales sobre pasajes paralelos; a otras notas de contenido diverso remite el texto mismo por medio de letras minúsculas que se reinician en cada capítulo;

- los contenidos de estas últimas notas son, en su mayoría: sencillas aclaraciones semánticas, contextualización histórica de 
pasajes proféticos y sapienciales y, una vez más, alusiones tipológicas al Nuevo Testamento.

Algunos de estos encabezamientos y notas fueron total o parcialmente tachados por manos inquisitoriales en el ejemplar que manejamos (Biblioteca Nacional de Madrid R/22276). La censura fue aplicada exclusivamente al Antiguo Testamento.

Tras la edición del texto bíblico, con página y media explicativas, dirigidas al florentino Tomás Sartini, se edita el Liber interpretationum Hebraicorum Graecorumque nominum ${ }^{12}$, fruto de la colación de doce ejemplares latinos, con el fin de facilitar la identificación de esos nombres, tanto en la edición misma como en la Vulgata de Jerónimo. Este Liber interpretationum lleva numeración específica, en el margen inferior de la página, compuesta por letras, nombres y números romanos.

La obra se cierra con una página de Errata.

\subsection{Análisis}

La importancia de la edición de Servet no reside en el texto bíblico en sí mismo, sino en las aportaciones que, al parecer, introdujo a través de las notas marginales y los encabezamientos, como afirma en el Prólogo que antepuso a la edición.

En este apartado trataremos de los tres aspectos de la edición que nos parecen más significativos:

1. prólogo de Servet, que nos informa sobre su trabajo editorial en esta Biblia;

2. encabezamientos a los distintos capítulos;

3. notas marginales: carácter y censura.

12 En la titulación, falta el término Arabicorum, que vuelve a aparecer al final del índice, en lá subscripción. 


\subsubsection{Prólogo de Servet}

Fue traducido por A. Alcalá, a partir del ejemplar de la Biblioteca Pública de Nueva York ${ }^{13}$. Por él sabemos que:

- Servet era muy consciente de la dificultad de traducir las Escrituras. Como ejemplo ilustrativo cita el Prólogo de Ben Sira («los términos hebreos se marchitan o entorpecen al ser traducidos a otra lengua»), y afirma que cuantos han intentado interpretar la Biblia no lo han conseguido cabalmente;

- critica a quienes menosprecian el sentido histórico y literal y «andan a la caza de interpretaciones místicas»;

- defiende el estudio del hebreo y de la historia, «antes de abordar la lectura de los profetas», con citas de Juan y Pablo, y advierte de que la historia prefiguraba el futuro e incluía los misterios de Cristo, pero que el sentido literal de los profetas era otro en su tiempo, «a tono con la historia de lo acaecido»;

- explica claramente su esfuerzo por «mostrar ese sentido viejo literal o histórico, tan frecuentemente menospreciado, a fin de que por su tipo comparezca el místico, el verdadero».

En el ejemplar de la Biblioteca Nacional de Madrid hay un párrafo final que parece faltar en el que se conserva en la Biblioteca Pública de Nueva York (puesto que A. Alcalá no lo incluye en su traduccion ${ }^{14}$ ), de gran interés para conocer la aportación de Servet, por lo que lo hemos traducido con la mayor literalidad posible ${ }^{15}$ :

En lo cual, así como en la versión misma de nuestro Pagnino, nos hemos esforzado no poco después de todas sus anotaciones. Anotaciones, digo, que nos dejó aquél en gran número; no sólo

\footnotetext{
13 A. Alcalá, Restitución del Cristianismo (Madrid 1980) págs. 76-77.

${ }^{14}$ Este párrafo sí aparece en la reproducción del mismo Prólogo del ejemplar de la Biblioteca Nacional de Madrid, lámina 18 de la edición de A. Alcalá.

${ }^{15}$ Las cursivas son nuestras.
} 
anotaciones, sino también el ejemplar mismo corregido por su propia mano en numerosos pasajes. Por todo lo cual me atrevería a afirmar que ahora las frases están más completas y más próximas a la verdad hebrea. Sin embargo, juzgue de ello la Iglesia y los expertos en hebreo; porque otros no lo pueden juzgar. Cualquier ventaja, lector, que saques de ello, se lo agradezco primero a Dios Óptimo Máximo, después a Hugo, ciudadano de Porta Lugdunense, con cuyo trabajo y gastos sale esto a la luz. Vale ${ }^{16}$.

De este párrafo se desprende que Servet trabajó con un ejemplar corregido y anotado por Pagnino ${ }^{17}$, aunque presumió de haberse esforzado en completar y mejorar el material recibido. En el proceso de Ginebra el propio Servet admitirá su autoría «parcial» de las notas.

\subsubsection{Encabezamientos}

Los encabezamientos que figuran en la edición de Servet no se encuentran en la edición de Pagnino. Sin embargo, Pagnino editó al principio de su Biblia ${ }^{18}$ una lista abreviada del contenido de los distintos libros de la Biblia hebrea, que no tiene nada que ver con los encabezamientos de la edición de Servet.

Aunque tanto el judaísmo normativo como el cristianismo naciente partieron del mismo corpus textual para definir los cánones de sus

\footnotetext{
${ }^{16}$ In qua re, sicut et in ipsa Pagnini nostri versione, non parum est nobis post omnia eius annotamenta desudatum. Annotamenta, inquam, quae ille nobis quam plurima reliquit. Nec solum annotamenta, sed et exemplar ipsum locis innumeris propria manu castigatum. Ex quibus omnibus affirmare ausim, et integras magis nunc esse sententias, et Hebraicae veritati propinquiores. Ecclesiae tamen, et Hebraice peritorum sit de hac re iudicium: alii enim id iudicare nequeunt. Quicquid verò commodi hinc lector retuleris, primum Deo, OPT. MAX. deinde HVGONI à Porta Lugdunensi ciui gratias agito cuius opera et impensis haec in lucem prodeunt. Vale.

17 R. H. Bainton, Servet, el hereje perseguido (Madrid 1973) pág. 108, menciona una edición no autorizada de Pagnino (Colonia 1541) que Servet pudo haber utilizado también.

${ }^{18}$ Págs. allb y ss.
} 
respectivas comunidades (Biblia hebrea, para los judíos; Antiguo Testamento, para los cristianos), lo que terminó por dividir a ambos grupos religiosos fue la interpretación de esos textos. Y es que los cristianos vieron en ellos el anuncio de las profecías que se habían cumplido en Jesús de Nazaret, el Mesías. Desde esta perspectiva se compusieron los escritos del Nuevo Testamento, sobre la trama y la urdimbre de textos veterotestamentarios ${ }^{19}$ : comenzó así la lectura cristiana de la Biblia hebrea.

Pero el texto sagrado era un texto intocable (herencia también judía), de forma que cualquier interpretación, comentario o referencia, incluso en las traducciones del original hebreo, sólo podía encontrar cabida en los encabezamientos de los capítulos o en forma de notas marginales, que se convirtieron, en el siglo XVI, en una especie de guía doctrinal para el lector ${ }^{20}$.

Los encabezamientos de la edición de Servet pueden clasificarse en:

a) breves descripciones del contenido del capítulo;

b) cristianizaciones del texto -especialmente en los profetasmediante alusiones tipológicas al Nuevo Testamento;

c) resúmenes sospechosos de herejía, que fueron tachados por manos inquisitoriales.

${ }^{19}$ Cf. W. DitTMaR, Vetus Testamentum in Novo. Die alttestamentlichen Parallelen des Neuen Testaments im Wortlaut der Urtexte und der Septuaginta, I und II (Gotinga 1899/1903); actualizado en el nuevo proyecto iniciado por $\mathrm{H}$. HÜBNER, Vetus Testamentum in Novo, 2, Corpus paulinum (Gotinga 1997).

${ }^{20}$ Pero estas notas fueron una fuente de problemas. Así, las de la edición de R. Estienne de 1545, reportata tomados en las clases impartidas por Vatablo, y de carácter luterano, provocaron que la edición fuera pronto incluida en todos los índices de libros prohibidos. La Biblia de Vatablo fue impresa en Salamanca por G. de Portonariis, después de haber sido sometida a correcciones por una comisión de autoridades universitarias salmantinas. Tres de estos revisores (Luis de León, G. de Grajal y M. Martínez de Cantalapiedra) fueron denunciados por algunos colegas por haber criticado la Vulgata durante las sesiones de la comisión. En 1613 y 1632 los ejemplares de esta Biblia fueron sometidos a nuevas correcciones; en 1790 volvió a ser incluida en el índice de libros prohibidos. Cf. D. BARTHÉLEMY, «Origine et rayonnement de la Bible de Vatable», en Découvrir l'Écriture, ed. D. BARTHÉLEMY (París 2000) págs. 109-122. 
Aunque los descriptivos son los más numerosos, seleccionamos sólo tres ejemplos de los mismos, a modo de ilustración, puesto que carecen de interés filológico; incluimos algún ejemplo más de los casos de cristianización del texto, para apreciar las sutiles formas utilizadas para leer en clave cristiana el Antiguo Testamento; y, con el fin de detectar los modos de proceder inquisitoriales, estudiamos todos los encabezamientos tachados.

a) Encabezamientos descriptivos:

- Génesis 11: Aedificatio Babel, confusio linguarum, genealogia Sem filii Noach, usque ad Abram;

- Isaías 30: Comminatur iis qui in Aegyptum ab Assyriis fugiebant;

- Salmo 7: Sighaion David quod cecinit domino super verba Chus filii Iemini.

b) Encabezamientos cristianizantes ${ }^{21}$ :

- Isaías 5: De Christo eiusque vinea;

- Isaías 11: Praedicit nativitatem Christi eiusque contra Antichristum victoriam et conversionem reliquiarum Israel;

- Isaías 32: De Christi ac Apostolorum eius adventu;

- Isaías 42: De Christo eiusque adventu sub Cyri typo, et de baptismo;

- Isaías 52: Excitatur ecclesia ad virtutes, laudantur apostolici praedicatores, describitur Christi humilitas;

- Isaías 53: Praedicit Christi passionem;

- Isaías 61: In persona Christi loquitur propheta;

- Jeremías 11: Praedicit Christus se crucifigendum;

- Miqueas 5: De Christo nascituro ex Bethlehem;

- Zacarías 9: De Christo ascensuro asinam et pullum eius;

${ }^{21}$ Especialmente numerosos en el libro de Isaías. 
- Zacarías 11: Calamitas templi secundi sub Antiocho. Christum tradendum pro triginta argentis. De pastore Antichristo.

Sorprende el que no haya encabezamientos cristianizantes en el libro de los Salmos, ni siquiera en los interpretados tradicionalmente como mesiánicos por los autores del Nuevo Testamento (como el Salmo 22, en numeración hebrea). ¿Era difícil el cristianizarlos por la atribución de su autoría a David mismo, o era tan evidente su mesianismo que no se necesitaba explicación alguna? El primer versículo de algunos Salmos hebreos contextualiza la situación en la que fueron supuestamente compuestos; esta incipiente historización está más desarrollada en la traducción de Septuaginta. En los encabezamientos de los Salmos de la Biblia de Servet se traducen los títulos hebreos descriptivos del contenido de estos Salmos y se desarrolla todavía más el contexto histórico que los relaciona con David y los libros de los Reyes.

c) Encabezamientos tachados:

En el ejemplar de la Bibloteca Nacional de Madrid hay cinco encabezamientos censurados con tachaduras ${ }^{22}$ :

- Salmo 110 (numeración hebrea) ${ }^{23}$ : Scilicet Salomoni, quem ut Christi typum eum dominum vocat David, translato iam in eum tanto regno 1 Para 29. Sciebat David de se oriturum dei filium dominatorem orbis: ideo sub dilecti filii typo eum dominum vocat. Citato etiam loco dicitur Salomon sedisse super solium Dei secundum fortitudinem dei a dextris dei in umbra scilicet;

- Isaías $2{ }^{24}$ : Adventum Ezechiae iuxta litteram praedicit, et

\footnotetext{
${ }^{22}$ Gracias al Profesor A. Alcalá, quien nos transcribió el contenido de estas tachaduras, tanto en los encabezamientos como en las notas, a base del ejemplar de la Biblioteca Pública de Nueva York, hemos podido recuperar el texto de estas censuras.

${ }^{23}$ Salmo de entronización real, citado a menudo en el Nuevo Testamento y en los textos de Qumrán; la nota tachada lo aplica a Salomón.

${ }^{24}$ Describe la gloria mesiánica de Sión. La nota tachada lo aplica literalmente a Ezequías.
} 
describit Israelis vocationem ad Ierusalem, perditis sine gladio Assyriis;

- Isaías $9^{25}$ : Prophetat Christi nativitatem, eiusque imperium, typo Ezechiae;

- Isaías $50{ }^{26}$ : De Iudaeorum improbatione, in Christi passione sub typo Esaiae;

- Zacarías $11^{27}$ : Párrafo tachado entre el título y el texto, que no remite a nota marginal ${ }^{28}$.

La censura inquisitorial no admitió asociar a Salomón, Ezequías e Isaías con estos pasajes aplicados mesiánicamente a Cristo en el Nuevo Testamento, pese a la especificación en las notas de que se trataba de «tipos» que prefiguraban al Mesías. No se admitió la interpretación literal o histórica de estos pasajes, aunque se reconociera en ellos el sentido místico o tipológico referido a Cristo.

Curiosamente, algunos de los encabezamientos censurados en el Índice de Sotomayor $(1667)^{29}$, de contenido similar, no fueron censurados en el ejemplar de la Biblioteca Nacional de Madrid. Frente a los cinco encabezamientos censurados en este ejemplar, en el índice de Sotomayor se censuraron veinte, entre ellos seis del Nuevo Testamento ${ }^{30}$. Los motivos de estas censuras pudieron ser diversos: en los encabezamientos de Deuteronomio, el énfasis en el cumplimiento de la Ley; en Job, dudas sobre la justicia humana; en Eclesiastés, sobre la alegría del vivir.

\footnotetext{
${ }^{25}$ Profetiza el nacimiento y el reino del Mesías.

${ }^{26}$ Canto tercero del siervo de Yahweh.

${ }^{27}$ Alegoría del profeta pastor.

${ }^{28}$ En opinión del Prof. Alcalá, «larga nota totalmente inocua».

${ }^{29}$ Según el texto de H. van Allwoerden, Historia Michaelis Serveti (Helmstedt 1727-1728) págs. 192-195.

${ }^{30}$ A los cinco ya mencionados se añaden Deuteronomio 4; Deuteronomio 6; Deuteronomio 13; Deuteronomio 15; Job 9; Proverbios 5; Eclesiastés 9; Eclesiástico 39; Jeremías 7; Romanos 2; Romanos 10; Gálatas 2; Gálatas 3; 2 Tesalonicenses $3 ; 1$ Juan 5 .
} 
Sin embargo, en los pasajes del Nuevo Testamento está clara la intencionalidad de la censura: la mayoría afectan a formulaciones de ecos de la Reforma que insisten en la justificación por la fe y la palabra.

\subsubsection{Notas marginales: carácter y censura}

Las notas marginales en el Antiguo Testamento, con exclusión de las que consignan lugares paralelos, son casi dos mil, frente a las seis que presenta el Nuevo Testamento. Los libros más anotados del Antiguo Testamento - téngase en cuenta la extensión de los mismos - son Salmos (301), Isaías (246), Profetas Menores (172), Jeremías (129) y Ezequiel (126).

Las notas marginales son de seis tipos ${ }^{31}$ :

a) indicación de pasajes paralelos;

b) sinónimos latinos;

c) notas explicativas;

d) breves comentarios de carácter histórico;

e) notas filológicas;

f) notas tachadas.

Las notas y su autoría constituyen el material más polémico de la edición de Servet. De ahí que este epígrafe sea el más extenso de nuestro trabajo.

a) Indicación de pasajes paralelos: cf. nota 31 .

b) Sinónimos latinos: se trata de breves notas, casi todas de carácter estilístico, que tienden a aclarar el sentido del texto:

\footnotetext{
31 Prescindimos del estudio de los lugares paralelos (apartado a), porque son meras referencias a contextos similares en el Antiguo Testamento, y a citas y alusiones del Antiguo en el Nuevo. En los apartados b-e hemos cotejado tan sólo, aunque de forma exhaustiva, las notas correspondientes a Génesis, Salmos e Isaías. En el apartado f se estudian todas las notas tachadas por la Inquisición.
} 
- Salmo 18,46: frente al a carceribus suis del texto de Pagnino, Servet anota de ergastulis suis. Ergastulum significa 'prisión de esclavos'; la nota no trata de facilitar la comprensión, sino que refina el sentido, más allá del hebreo 'fortines');

- Salmo 23,5: frente al contra hostes meos de Pagnino, Servet anota videntibus hostibus meis, ablativo absoluto, construcción puramente latina, que nada tiene que ver con la preposición hebrea $T$ गุ?

c) Notas explicativas, algo más largas, que ilustran el sentido del pasaje:

- Génesis 4,23: Servet anota el texto de Pagnino si virum occidero in vulnere meo de la forma siguiente: quia ferro utor. obiurgabat eum ab uxoribus de armorum usu. Comenta que a Caín le reprochaban sus esposas el uso de las armas;

- Génesis 17,1: Pagnino traduce: Erat Abram filius nonaginta annorum et novem annorum; Servet anota en filius: vir. Aclara el hebraísmo 'hijo de x años', que indica la edad del sujeto al que se refiere. Pagnino y Arias Montano mantienen el hebraísmo 'hijo de $\mathrm{x}$ años';

- Génesis 20,16: Pagnino traduce: Ecce est tibi operimentum oculorum; Servet anota: Ecce hoc tibi velut ad occultandam pulchritudinem tuam, et apud eos qui tecum sunt, et apud reliquos omnes (ne scilicet quem tentes) et castigaveris, seu esto causa ne mentiaris esse fratem qui maritus est. Nota explicativa, que ni siquiera había desarrollado el Targum;

- Salmo 8,3: Pagnino traduce: Ex ore parvulorum et lactantium fundasti fortitudinem..., y Servet anota a fundasti: stabilisti scilicet pueris clamantibus Davidi decem milia sicut Christo Hosihahna; Arias Montano mantiene el fundasti de Pagnino;

- Salmo 10,4: Pagnino traduce: Impius... non quaeret deum, y Servet anota: non requirit, scilicet corde, sed ore tantum laudat. Podría interpretarse como un ataque al ritualismo y oración vocal, frente a la piedad interior, con lo que supone de resonancias erasmistas; 
- Isaías 40,23: Pagnino traduce: Cui igitur assimilabitis deum et quid similitudinis ponetis ei, y Servet anota: Miris modis rudes Iudaeos inducit, ut redemptionem a Babylonica captivitate futuram, non ab idolis esse credant, sed a creatore deo qui et haec praedicit antequam fiant.

d) Breves comentarios de carácter histórico, especialmente en Salmos e Isaías, que intentan aplicar el texto a personajes concretos de la historia de Israel:

- Salmo 1,1: Pagnino traduce: Beatus vir qui non ambulavit in consilium impiorum, y Servet anota: impium Achitophelis consilium huius psalmi fuit occasio, sicut quinque sequentium. Aplica a 'Ahîtófel, consejero de David, pero implicado en la conjura de Absalom ${ }^{32}$, un salmo relativo a la distinta suerte de justos e impíos; la misma interrelación se establece en el Salmo 5,7

- Salmo 7 (título): Pagnino traduce: Sighaion David quod cecinit domino super verba Chus filii Iemini, y Servet anota a la palabra Chus: Saulis. Según F. Cantera ${ }^{33}$ : «Se ignora quién fue el Kus que motivó este salmo. Tal vez algún criado de Saúl (2 Samuel $18,21 \mathrm{ss}$ ) si es nombre de persona y no gentilicio (= etíope)»;

- Salmo 11,1: Pagnino traduce: quomodo dicitis animae meae, ut transmigret a monte vestro, y Servet comenta en nota a monte vestro: scilicet terrae Iehudah metu Saulis obsidentis;

- Salmo 17,11: Pagnino traduce: oculos suos posuerunt ad declinandum in terram, y Servet anota: inclinatos scilicet ad spectandum vestigia pedum instar leonis praedae vestigium sequentis. Hoc enim modo Saul sequebatur Davidem;

- Salmo 22 (título): Pagnino traduce: Victori super cervam diluculi canticum David, y Servet anota: ut cerva ab ineunte die a canibus afflicta orat hic David;

${ }^{32}$ Cf. 2 Samuel 15,12 y ss.

${ }^{33}$ F. CAntera Burgos y M. Iglesias GonZÁlez, Sagrada Biblia ( $3^{\text {a }}$ ed. Madrid 2000) pág. 608, nota 1 . 
diluculi canticum David, y Servet anota: ut cerva ab ineunte die a canibus afflicta orat hic David;

- Salmo 24,3: Pagnino traduce: Quis ascendet in montem domini, y Servet anota: scilicet Morija ad inducendam arcam domini;

- Isaías 8,10: Pagnino traduce: quia nobiscum deus, y Servet anota: quia Immanuel, id est, quia Deus est cum Ezecgia (sic) contra Assyrios. El pasaje había sido aplicado en la tradición cristiana a Cristo; relacionarlo con Ezequías podría socavar su carácter mesiánico;

- Isaías 11,4: Pagnino traduce: spiritu labiorum suorum interficiet impium, y Servet anota (en nota tachada, pero legible): sola oratione vicit Ezechias impium Assyrium hyperbole enim quadam. Ezechiae tribuitur quae soli Christo vere conveniunt qui et per spiritum suum interficiet antichristum ut 2 Thes. $2^{34}$.

e) Notas filológicas que ponen de manifiesto conocimientos del original hebreo por parte de su autor:

- Génesis 1,2:

Hebreo: ורוח אלהים מרחפת על פני המים;

Vulgata: spiritus Dei ferebatur super aquas;

Pagnino: spiritus Dei flabat in superficiem aquarum;

Servet: ventus vehemens agitationem faciebat super faciem aquarum;

Arias Montano: spiritus Dei motabat super facies aquarum.

La traducción literal del hebreo es: «y el espíritu de 'Elohîm se cernía por encima de las aguas». En hebreo, como en otras lenguas, hay palabras de contenido semántico extremo (como 'dios', 'muerte') que se utilizan para expresar el superlativo. Ni las traducciones griegas (Septuaginta, Áquila, Símaco y Teodoción), ni la Vulgata, ni Pagnino, ni Arias Montano reflejan el sentido del original, que sólo parece haber sido reconocido por Servet. El ventus vehemens de Servet tampoco parece dependiente de las traducciones castellanas

${ }^{34} 2$ Tesalonicenses 2,8 ss., donde se menciona al impío al que Jesús matará con el soplo de su boca. 
más fieles al hebreo, como Ferrara: «y espirito del dio se mouia sobre façes de las aguas», y Biblia de Alba: «E el spiritu del Señor era rretraydo sobre fazes de las aguas».

- Génesis 2,7:

Hebreo: וייצר יהוה אלהים את האדם עפר מן האדמה;

Vulgata: de limo terrae;

Pagnino: e pulvere terrae;

Servet: pulverem e terra;

Arias Montano: pulverem de terra.

La traducción literal del hebreo es: «Y formó Yahweh 'Elohîm al hombre, polvo de la tierra». Servet se ajusta más al original hebreo que Vulgata y Pagnino, porque coloca la preposición latina en el lugar correspondiente a la preposición hebrea. Arias Montano corrige a Pagnino con el mismo criterio que Servet.

- Génesis 2,7:

Hebreo: ויפח באפיו נשמת חיים;

Vulgata, Pagnino y Arias Montano: faciem;

Servet: nares.

La traducción literal del hebreo es: «e insufló en sus narices aliento de vida». Pese a que la palabra hebrea אף admite las dos acepciones ('nariz' y 'rostro'), Servet elige el vocablo menos acorde con la lengua término, y, además, mantiene el plural de la palabra hebrea, como hicieran los traductores más literales del hebreo al griego, Áquila y Teodoción: ambos emplean el plural $\mu \nu \kappa \tau \hat{\jmath} \rho \alpha \varsigma$, frente al $\pi \rho o ́ \sigma \omega \pi$ ov de la Septuaginta. Incluso en una versión tan literal como la de Ferrara, encontramos la traducción, en singular, 'nariz' ${ }^{35}$, que en Alba es traducido, también en singular, por ' $f a z$ ' ${ }^{36}$, como Vulgata, Pagnino y Arias Montano.

35 «y soplo en su nariz aliento de vidas»; cf. Biblia En lengua Española traduzida palabra por palabra dela verdad Hebrayca por muy excelentes letrados vista y examinada por el officio de la Inquisicion, Ferrara 1553; edición facsimilar a cargo de I. M. HASSÁN y U. MACÍAS CAPÓN (Madrid 1992).

36 «e spiro en su faz spiraculo de vidas»; cf. Biblia traducida del hebreo al castellano por Rabi Mose Arragel de Guadalfajara (1422-1433?) y publicada por el DuQue De Berwick y De AlbA (Madrid 1920). 
- Génesis 4,13:

Hebreo: גדול עוני מנשא;

Vulgata: maior est iniquitas mea quam ut veniam merear;

Pagnino: maior est punitio mea quam ut ferat;

Servet: maior est iniquitas mea quam ut exaltet;

Arias Montano: maior est iniquitas mea quam parcere.

La traducción de la raíz hebrea נשא es más literal en el exalto de Servet que en los verbos utilizados por los otros traductores.

- Génesis 4,14:

Hebreo: נע ונד;

Vulgata, Pagnino y Arias Montano: vagus et profugus;

Servet: tremens, trepidans.

La traducción literal del hebreo es: «agitado y tembloroso»; la traducción de Servet es más literal e intenta, además, reproducir la aliteración inicial del hebreo (dos palabras que empiezan con la misma sílaba: ১̦ en hebreo, tre- en latín). Que la traducción se basa en el hebreo se confirma por la versión que Servet hace de נוד en Génesis 4,16: tremoris.

- Génesis 44,5:

Hebreo: נחש ינחש בו:

Vulgata: in quo augurati solet;

Pagnino: tentando tentat in eo;

Servet: augurando augurat propter eum;

Arias Montano: augurando augurabitur in eo.

La traducción literal del hebreo es: «augurar augurará con él». Puesto que en el pasaje se trata de un caso de lecanomancia, resulta más literal la nota de Servet, mantenida por Arias Montano, que la traducción de Pagnino. La construcción hebrea de infinitivo más forma personal para indicar aseveración se mantiene en Pagnino, Servet y Arias Montano, que utilizan un gerundio - forma más 
aceptable en la lengua término que el infinitivo hebreo- más la forma personal.

- Salmo 2,1:

Hebreo: רגשו;

Vulgata iuxta Heb.: turbabuntur;

Vulgata iuxta LXX: fremuerunt;

Pagnino: congregabunt se;

Servet: tumultuabuntur;

Arias Montano: tumultuatae sunt.

La traducción literal del hebreo es: «se alborotaron». Servet es más literal que Pagnino, no sigue las traducciones de Vulgata, y el verbo latino por él elegido lo mantiene Arias Montano.

- Salmo 8,6:

Hebreo: ותחסרהו מעט מאלהים;

Vulgata iuxta Heb.: a Deo;

Vulgata iuxta LXX: ab angelis;

Pagnino: ab angelis;

Servet: a diis, illustribus viris quibus in persecutionibus factus est inferior David Christi typus postea scilicet coronandus;

Arias Montano: a Deo.

La traducción literal del hebreo es: «algo menor lo hiciste que los dioses». El más literal es Servet: no sólo mantiene la acepción 'dios', suavizada en Vulgata iuxta LXX y en Pagnino, sino el problemático plural 'dioses', tan debatido en la historia de la exégesis; sin embargo, desvirtúa la nota filológica, al entender el término 'dioses' como 'varones ilustres' de la época de David.

- Is 36,12 :

Hebreo: מימי רגליהם (= = 'sus orines') y, al margen (las aguas de sus pies'); 
Vulgata: urinam pedum suorum;

Pagnino: aquas pedum suorum;

Servet: aquas capitis vocant Hebraei lachrymas, et aquam pedum urinam;

Arias Montano: urinas suas, y al margen indica la lectura sinagogal: מימי רגליהם.

En el Antiguo Testamento hebreo hay ocasiones en las que el texto escrito podía resultar obsceno o malsonante para los oídos de los fieles que asistían al servicio sinagogal ${ }^{37}$. En esos casos, al margen del texto hebreo aparece un sinónimo que suaviza la obscenidad de lo escrito y que es lo que ha de leerse en la liturgia. En este caso, Pagnino sigue la lectura eufemística, que la Vulgata no juzgó necesario suavizar; Servet la conoce y explica los eufemismos hebreos; y Arias Montano, con evidente conocimiento de la transmisión del texto del original del Antiguo Testamento, consigna al margen, en hebreo, la lectura eufemística sinagogal.

Las notas filológicas de la edición de Servet afectan en ocasiones a nombres propios que son traducidos como nombres comunes de similar grafía. Así:

- Génesis 11,31:

Hebreo: מאוּר כשדים = de Ur de los caldeos;

Vulgata: de Ur Chaldeorum;

Pagnino: de Ur Chasdim;

Servet: igne Chaldaeorum;

Arias Montano: de Ur Chasdim.

El primer significado del hebreo אוּר es 'luz' o 'luz de fuego'.

- Génesis 14,3:

Hebreo: עמק השדים = valle de Siddim;

${ }^{37}$ Cf. R. Gordis, The Biblical Text in the Making. A Study of the Kethib-Qere (Nueva York 1971) pág. 86. 
Pagnino: in valle Siddim;

Vulgata: in vallem Silvestrem;

Servet: anota a Siddim 'agrorum', identificando el nombre propio con un hipotético plural de שדים, שדה, sin justificación filológica alguna, sino por mera asociación gráfica. El plural hebreo de es שָדiֹ;

Arias Montano: ad vallem Siddim.

En estos dos casos las notas de la edición de Servet reflejan etimologías populares acuñadas para una posible intelección de los nombres propios.

f) Notas tachadas ${ }^{38}$ :

Las notas objeto de tachadura, sesenta y tres, más los cinco encabezamientos antes tratados del ejemplar de la Biblioteca Nacional de Madrid ${ }^{39}$, pueden clasificarse en dos grupos desiguales, que anotamos de menor a mayor, según la importancia de su contenido:

- notas explicativas, en las que no es fácil comprender la razón de la censura;

- notas a pasajes de carácter mesiánico, muchos de ellos citados en el Nuevo Testamento como referidos a Cristo, en los que la inquisición no admitió la interpretación histórica literal.

En ninguna de estas notas se percibe un debate filológico sobre el texto, ni confrontación con las versiones antiguas. El trasfondo es puramente exegético.

- Notas explicativas:

- Isaías 7,11: la nota tachada al texto de Pagnino profunda te ipsum dice: id est, in profundo vel in excelso signum pete.

${ }^{38}$ Cf. nota 31.

${ }^{39}$ Frente a las cuarenta y tres notas más tres encabezamientos señalados por $\mathbf{J}$. M. de Bujanda, en su comentario a los Índices de Gaspar Quiroga, Index de l'Inquisition espagnole 1583, 1584 (Ginebra 1993) pág. 791. 
¿Qué censuraron? ¿Una posible alusión al Seol? ¿La búsqueda de signos adivinatorios en el cielo? Porque la nota parece simplemente un intento de aclarar la oscura traducción de Pagnino, Pete tibi signum a domino: deo tuo: profunda te ipsum petendo, vel eleva temetipsum in excelsum, que ni siquiera es literal respecto al hebreo. Arias Montano, en sus correcciones a Pagnino, edita: Pete tibi signum a cum [hebreo מאם] Domino Deo tuo profunda petitionem vel eleva te ipsum in excelsum.

- Isaías 52,14: la nota tachada al texto de Pagnino sic corruptus est prae viro aspectus ei dice: quod ita deformatus esset praeter humanum morem aspectus eius.

Quizá tachada por la dureza empleada en la descripción del siervo de Yahweh, aplicada por los evangelistas a Cristo en la cruz.

- Zacarías 11,8: la nota tachada al texto de Pagnino tres pastores dice: triplex erat pastorum genus: principum, sacerdotum et prophetarum.

Identifica las tres clases de pastores, príncipes, sacerdotes y profetas, con las tres jerarquías dominantes en la historia de Israel, en consonancia con la antigua escuela exegética de Antioquía, que había sobresalido por su interpretación histórica literal del Antiguo Testamento.

- Notas a pasajes de carácter mesiánico:

En estos textos se subraya la identificación de los personajes implicados con figuras históricas, como David, Salomón, Ezequías, Ciro o Zorobabel. En casi todos ellos se menciona también la interpretación mesiánica, en sentido profético o tipológico, pero las tachaduras revelan que, incluso reconociendo la lectura mesiánica, no se toleraba la lectura literal que marcaba el contexto.

- Isaías 7,14: la nota tachada al texto de Pagnino ecce virgo dice: Id est, ostendit ad litteram ipsam Abiam praesentem et parituram Ezequiam, qui et fortitudo Dei et immanuel, et ante cuius regnum perditi sunt duo illi reges hostes Iudeae ut 4 Reg. 16 et 19. 
El pasaje se cita en el Nuevo Testamento como testimonio de la concepción virginal de María, con el apoyo del texto de Septuaginta, que traduce el hebreo עלמה como $\pi \alpha \rho \theta \varepsilon$ ćvos (= 'virgen') y no como $v \varepsilon \tilde{\alpha} v i \varsigma$ (= 'doncella'). La nota tachada lo enmarca en su contexto histórico, referido a Abías, madre de Ezequías, con remisión a los pasajes del libro de los Reyes que tratan de Ajaz y Ezequías. En esta ocasión se silencia la interpretación mesiánica de la tradición cristiana.

- Isaías 11,4: la nota tachada al texto de Pagnino spiritu labiorum suorum interficiet impium dice: Sola oratione vicit Ezequia impium Assyrium, hyperbole enim quadam Ezechiae tribuuntur quae soli Christo vere conveniunt qui et per spiritum suum interficiet antichristum ut 2 Thes. 2. Omnia haec iuxta litteram semel sequuta sunt post divinam illam Assyriorum cladem, et iterum in spiritu sequitura praedicantur.

En 2 Tesalonicenses 2,8 se habla del adversario de los últimos tiempos, el impío, en la tradición cristiana el Anticristo, «al que el Señor Jesús matará con el soplo de su boca». Pese a la defensa clara que se hace en la nota de que el texto debe ser aplicado soli Christo, la contextualización histórica, que lo aplica al triunfo de Ezequías sobre los asirios, es censurada. A diferencia del ejemplo anterior, se especifica claramente la distinción entre el sentido literal (iuxta litteram semel) y el sentido espiritual (in spiritu) referido a acontecimientos futuros.

- Isaías 40,3: la nota tachada al texto de Pagnino vox clamantis in deserto dice: Ad Cyri regis imperium facta est praeconio vox ut per deserta quaevis loca pateret via Israelis a Babylonia redeuntibus. Unde sumpta occasione in Christum rapitur propheta, vide Ieremias 31 .

En Jeremías 31 se relata la nueva alianza entre Yahweh y su pueblo, al retorno del exilio babilónico. Los evangelistas (Mateo 3,3 y Lucas 3,4) aplican este texto de Isaías a Juan el Bautista, precursor del Mesías; la nota lo aplica en primer lugar a Ciro, que permitió el retorno de los judíos exiliados, y después admite que, llegada la 
ocasión, el profeta, es decir, el evangelista, la usurpó para aplicársela a Cristo. La razón de la tachadura pudiera estar en la dureza del verbo utilizado (rapitur) para la interpretación mesiánica.

- Isaías 40,9: la nota tachada al texto de Pagnino ecce Deus vester dice: Hoc est ad litteram de Cyro, ut. c. 45.

En el capítulo 45,1 de Isaías, Yahweh califica a Ciro de «su ungido» (משיחו). Ciro aparece aquí como sucesor de David, liberador del pueblo, es decir, como Mesías. Adviértase la fuerza de la expresión ad litteram. La crítica más reciente reconoce que Ciro fue identificado por el autor del Deutero-Isaías con el legítimo sucesor de la dinastía davídica ${ }^{40}$.

- Isaías 42,6: la nota tachada al texto de Pagnino ego Domino vocavi te dice: Sublimitas horum verborum soli Christo convenit. Unde et Cyro tempore eius typo data est ad tempus ea mens, ut mitis esset, Iudaeis foedus servans, gentes ad Dei lucem efficiens, et in carceribus hallucinantes ad lucem ellucens. Fuit eorum ibi quaedam futurae veritatis adumbratio.

Un ejemplo más de aplicación histórica del texto a Ciro, aunque se subraye que el sentido más sublime del pasaje sólo conviene a Cristo. El momento histórico que representa Ciro fue como la sombra de una realidad futura personificada en Cristo.

- Isaías 53,5: la nota tachada al texto de Pagnino Ipse autem vulneratus est propter praevaricationes nostras dice: quasi exigentibus populi peccatis interfectum Cyrum deflet propheta eo quod postea sub Cambyse multo deterius habuerint, impedita tunc et diruta templi aedificatione iam inchoata. Dan. 9. Fuitque haec a Deo data occasio praedicandi passionem Christi cui soli convenit horum verborum sublimitas et veritas.

40 L. S. Fried, «Cyrus the Messiah? The Historical Background to Isaiah 45:1», Harvard Theological Review 95 (2002) págs. 373-393: pág. 374: «I suggest instead that the Deutero-Isaianic writer wrote as a contemporary of Cyrus, and that he wrote to legitimize him as the Davidic monarch, heir to the Davidic throne. The line of the Achaemenid kings would now take the place of the Davidides». 
De esta nota es interesante destacar que tan sólo han sido tachadas las primeras líneas (hasta inchoata) que recogen la interpretación literal del pasaje referido a Ciro, mientras que queda intacta la interpretación espiritual, que lo aplica a la pasión de Cristo.

- Jeremías 23,5: la nota tachada al texto de Pagnino germen iustum dice: De germine Zerubabel iuxta litteram, et quatenus in se regnum continet, vide apud Zaccariam. Referuntur haec mystice ad Christum, qui vere est deus noster et iustitia nostra, propheticus enim sermo gladius est utrinque scindens.

Oráculo mesiánico referido literalmente a Zorobabel, y espiritualmente a Cristo. Remite a Zacarías 9,9, pasaje claramente mesiánico, citado por Mateo 21,4-5 con ocasión de la entrada de Jesús en Jerusalén. En Zacarías 9,9 hay otra nota tachada al texto de Pagnino Ecce rex tuus veniet tibi que dice: In humili Zorobabel indicatur regnaturum germen. Matt 21.

- Daniel 9,25: la nota tachada al texto de Pagnino usque ad Christum ducem hebdomadae septem dice: Ab egressu praedicti ad me a deo sermonis de restituenda et aedificanda Ierusalem, usque ad ducem Cyrum Christum dei, qui id exequetur, hebdomades sunt septem: hebdomadisque sexaginta duabus restituetur et aedificabitur platea et fossa, in angustia scilicet temporum. Et post eas 62 hebdomadas occidetur Cyrus, et erit in nihilum: disipabitque aedificium et dessolabit Cambyses Cyro succedens, Foedus autem primum firmabit Darius: post quem item sequetur Antiochi abominatio stupenda et erit finis orbis Iudaici.

Interpretación histórica múltiple (aplicada a Ciro y a sus sucesores), que, en el Nuevo Testamento (en el comienzo del evangelio de Lucas) se aplica a Cristo ${ }^{41}$.

- Zacarías 11,13: la nota tachada al texto de Pagnino ad thesaurarium dice: ad figulum, ut in agro figuli fiat conglutinatio diruptarum virgae partium.

${ }^{41}$ Cf. F. Cantera Burgos y M. Iglesias González, Sagrada Biblia, pág. 798. 
El texto hebreo dice היוצר, de la raíz (= 'dar forma'); pero Pagnino traduce thesaurarium ('tesorero'), leído como האוצר, participio de la raíz אצר, y Servet como ad figulum ('alfarero'); Arias Montano traduce fictorem ('escultor') en los dos casos del versículo y saca al margen el thesaurarium de Pagnino; Vulgata traduce statuarium ('escultor de estatuas'); Septuaginta y Símaco

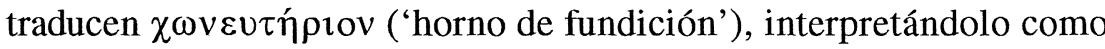
de la raíz צרף.

La nota marginal dice: «al alfarero, de forma que en el campo del alfarero se produzca el ensamblaje de las partes rotas del cayado». El figulum de esta nota no responde, pues, a Vulgata, pero sí al comentario a Zacarías de Jerónimo: ad figulum, qui creator et fictor est omnium... in domo figuli creatorisque omnium ${ }^{42}$.

- Salmo 22,17: la nota tachada al texto de Pagnino foderunt manus meas et pedes meos dice: Fugiente David per abrupta instar quadrupedis, manus et pedes perforabantur. Unde et Hebraei legunt: quasi leonis manus meae et pedes mei. At 70 pro Chearu legerunt Charu eamdem sententiam, et verum Christi mysterium.

En este pasaje cabe destacar la interpretación literal, personificada en David, y el recurso a las fuentes hebreas ${ }^{43}$ y griegas. El Salmo, siguiendo a la Septuaginta, es citado en el Nuevo Testamento, aplicado a la crucifixión de Cristo ${ }^{44}$.

Hemos comentado algunas de las notas más significativas, pero el elenco de interpretaciones literales históricas tachadas puede ampliarse, sin ánimo de ser exhaustivos:

- Números 24,17: identificación de David con el cetro que surgirá de Israel;

${ }^{42}$ Cf. D. BARTHÉlemy, Critique textuelle de l'Ancien Testament (Friburgo Gotinga 1992) vol. 3, pág. 992.

${ }^{43}$ Cf. E. Fernández Tejero, «Masora y Exégesis», en Simposio biblico español, eds. N. Fernández Marcos, J. Trebolle Barrera y J. Fernández VALLINA (Madrid 1984) págs. 183-192: págs. 185-187.

${ }^{44}$ Cf. Mateo 27,35; Lucas 23,34 y Juan 19,24. 
- Salmo 45,7: no niega la interpretación profética, pero refiere el pasaje a Salomón, Ciro y Moisés;

- Salmo 45,12: refiere el pasaje a Salomón, que desposó a la hija del faraón;

- Salmo 68,19: citado como mesiánico en el Nuevo Testamento ${ }^{45}$, aplicado a la resurrección de Cristo, la nota lo refiere a ad summitatem arcis Sion, en relación con 2 Samuel 5 y 1 Crónicas 2, donde se narra la derrota que infligió David a los jebuseos;

- Salmo 110: además del encabezamiento tachado, hay tres notas también tachadas, por haber aplicado a Salomón un salmo típicamente mesiánico;

- Cantar 6,9: aplica a la hija del faraón, preferida de Salomón, un texto interpretado en el cristianismo como mariano.

Hay varias notas tachadas por aplicar a Ezequías diversos pasajes de Isaías y de otros profetas tenidos por mesiánicos: Isaías 4,2; 19,20; 30,20 y 32,2; Oseas 2,2; 6,2; Miqueas 4,5; 4,14; 5,9. Otras, por haber sido aplicadas a Ciro: Isaías 43,$10 ; 45,8 ; 48,14.16 ; 49,6$; 51,$4 ; 52,13 ; 53,1 ; 60,6 ; 63,1$.

Los textos y anotaciones tachados que encontramos en el ejemplar de la Biblioteca Nacional de Madrid reflejan preocupaciones similares a las que se esgrimieron en los procesos inquisitoriales contra los hebraístas españoles del siglo XVI; es como si una única corriente de pensamiento invadiera los fundamentos teológicos de la época, más interesados, desde el punto de vista inquisitorial, en suprimir interpretaciones de carácter histórico — que no filológico- que pretendían contextualizar determinados pasajes del Antiguo Testamento atribuidos a Cristo en el Nuevo.

Sirva de ejemplo el caso del proceso incoado contra Alonso Gudiel, cuyas acusaciones coinciden con las censuras antes comentadas en pasajes como Cantar 6,9 (aplicado en sentido literal a los amores de Salomón con la hija del faraón), en la interpretación de algunos

${ }^{45}$ Cf. Efesios 4,8. 
Salmos como referidos a David, y en la interpretación histórica de relatos proféticos (como Zacarías 9,9 e Isaías 7,14) ${ }^{46}$.

Las notas al Nuevo Testamento son, en su mayoría, indicaciones de lugares paralelos, con la excepción de seis casos de carácter teológico o moralizante: Efesios 5,12; Hebreos 1,1; 11,32; Santiago 2,21; Apocalipsis 11,7; 16,16.

Las notas a Hebreos 1,1 y Apocalipsis 11,7 son meramente explicativas.

Nos parecen más relevantes las otras cuatro:

- Efesios 5,12, a propósito del matrimonio entre Cristo y la Iglesia, anota: id est, ecclesia constat ex carne et ossibus Christi, sicut Eva ex carne et ossibus Adae ideoque magno eucharistiae mysterio;

- Hebreos 11,32, al elogiar la fe de los antepasados e incluir algunos de los jueces como Gedeón y Barac, anota: Ad carnalem Hebraeorum populum scribens apostolus carnalium etiam hominum, nec omnino probatorum fidem commendat eo quod pie aliqui vixerint et mundanae fidei testimonia ediderint, ut vel hinc coelestis nostra in Christum fides commendabilior evadat;

- Apocalipsis 16,16, a propósito del topónimo Armaggedon, anota: Mons est iuxta aquas Meggidon ubi de coelo per Michaelem angelum pugnatum est contra hostes dei. Judicum 5. Et interpretatur Armegiddo mons delicatus. Exercitus vero dei erat in monte Thabor Judic. 4 ubi etiam convenerunt cum Christo Moses et Elias annunciante eodem angelo Jesum esse filium dei Mat. 17;

- En Santiago 2,21 hay una larga nota, que refleja la polêmica sobre la justificación por la fe o por las obras. Como Santiago defiende la importancia de las obras, la nota matiza: accessione scilicet ad priorem fidei iustitiam facta ut qui iustus est iustificatur adhuc.

${ }^{46}$ Cf. E. Fernández Tejero y N. Fernández Marcos, «Alonso Gudiel: ciencia y miseria», en Homenaje a G. Morocho [en prensa]. 


\section{SERVET ANTE LAS INQUISICIONES}

\subsection{La inquisición católica}

Las censuras inquisitoriales del ejemplar de la Biblioteca Nacional de Madrid coinciden, en general, con las recogidas en el Índice de Quiroga (1584). Es lógico, puesto que el ejemplar que manejamos fue corregido y expurgado en 1595, como dice una nota manuscrita de la portada.

Sin embargo, en el Índice de Antonio de Sotomayor (Madrid 1667) ${ }^{47}$, se censuran no sólo los textos tachados en el ejemplar de Madrid, sino también veinte encabezamientos más de capítulos, entre ellos, seis del Nuevo Testamento. Un índice de que la censura inquisitorial fue endureciéndose a lo largo del siglo XVII.

La inquisición católica condenó a Servet y sus obras ${ }^{48}$. Aunque la ejecución se realizó en efigie, la condena no fue menos dura que la dictada por la inquisición ginebrina. Con la diferencia de que, tras el proceso de Ginebra, el reo fue quemado lentamente, en carne y hueso, «sobre unos fajos de leños verdes y húmedos» ${ }^{49}$, mientras que, en la ejecución dictada por la inquisición católica, se tuvo «el detalle» de que la efigie del reo fuera ahorcada antes de ser sometida al fuego de la hoguera.

Los términos de la condena ginebrina son estremecedores:

Por estas y otras tan justas razones de las que nos ocupamos... y tras invocar el nombre de Dios... este Tribunal... teniendo ante nuestros ojos a Dios y sus Santas Escrituras, y hablando en nombre del Padre, del Hijo y del Espíritu Santo, damos nuestra sentencia y por escrito:

${ }^{47}$ Cf. H. van Allwoerden, «Historia Michaelis Serveti», págs. 192-195.

48 Cf. R. H. Bainton, Servet, pág. 173.

${ }^{49}$ Cf. A. AlCalá, Miguel Servet, pág. 86. Según Proceso de Ginebra [pág. 97 del ms. de la traducción de A. Alcalá, que nos ha facilitado el autor] el propio Servet gritó en medio de las llamas: «¿es que las doscientas coronas de oro que robasteis al meterme preso contra toda ley y el collar de oro que me arrancasteis del cuello no os bastaban para comprarme unos buenos troncos, traerlos aquí y acabar conmigo, pobre de mí?». 
Te condenamos a ti, Miguel Servet, a ser atado y conducido al lugar de Champel, y allí amarrado a una estaca y quemado con el libro escrito por tu mano que imprimiste hasta reducirte a cenizas ${ }^{50}$.

\subsection{La inquisición ginebrina}

Servet murió, pues, como consecuencia del proceso que se llevó a cabo en Ginebra.

Las principales acusaciones fueron de tipo dogmático. Sólo ocasionalmente aparecen las de carácter textual, por sus anotaciones a la Biblia de Pagnino.

Frente a las acusaciones de la inquisición católica a los hebraizantes, casi todas ellas centradas en la interpretación de pasajes del Antiguo Testamento ${ }^{51}$, más cercanas al texto hebreo que a las lecturas de la Vulgata, el proceso ginebrino contra Servet se basó, fundamentalmente, en discusiones teológicas en torno a la Trinidad y el bautismo, basadas en textos del Nuevo Testamento y de los Padres de la Iglesia prenicena.

En este proceso, las alusiones a las anotaciones de la Biblia de Pagnino son escasísimas. En las distintas fases del mismo aparecen en tres ocasiones: en un primer momento «confiesa haber anotado el libro de Ptolomeo y la Biblia, pero no cree haber hecho con ello nada malo» ${ }^{52}$; un testigo del proceso, De la Fontaine, «presenta un libro titulado Ptolomeo, que Servet confiesa haber anotado, así como una Biblia en la que Servet confiesa haber hecho algunas anotacio-

${ }^{50}$ Cf. A. Alcalá, Proceso de Ginebra, pág. 94.

51 Sobre el proceso de Gaspar de Grajal, cf. C. Miguélez Baños, Gaspar de Grajar: obras completas. I Estudio y edición (León 2000); vol. II [en prensa]; sobre el de Luis de León, cf. A. AlCALÁ, El proceso inquisitorial de fray Luis de León, Edición, introducción y notas por - (Valladolid 1991); sobre el de Martín Martínez de Cantalapiedra, cf. M. DE LA PinTa Llorente, Proceso criminal contra el hebraista salmantino Martín Martinez de Cantalapiedra (Madrid - Barcelona 1946); sobre el de Alonso Gudiel, cf. M. DE LA PINTA Llorente, Causa criminal contra el biblista Alonso Gudiel..., Edición y estudio por - (Madrid 1942).

52 A. Alcalá, Proceso de Ginebra, pág. 4. 
nes, pero no todas» ${ }^{53}$; en el tercer interrogatorio, respecto a los capítulos 7 y 8 de Isaías, «de cuyo último pasaje dicen que Servet ha atribuido a Ciro lo que se atribuye a Jesucristo en cuanto a borrar nuestros pecados y llevar nuestras iniquidades», Servet respondió

que lo principal debe ser entendido de Jesucristo, pero en cuanto a la historia y la letra debe atribuirse a Ciro, y que los antiguos doctores pusieron dos sentidos en el Antiguo Testamento, a saber, el sentido literal y el sentido místico, como así dice San Juan en el Apocalipsis en el capítulo 19, que el testimonio de Jesucristo es el espíritu de profecía, y acude a Nicolás de Lira como antiguo doctor, allí donde habla de Ciro, respecto al capítuío 53 de Isaías ${ }^{54}$;

y, por último, al final del proceso se alude a la interpretación histórica de la figura de Ciro en Isaías 53:

Pues hace doce años se imprimió en Lyón una Biblia cuyos márgenes ensució con sus muchas notas perniciosas. [iMientes, maldito bribón!] Bien saben los fieles que nunca mejor fue atestiguado el valor de la muerte de Cristo que en Isaías 53; pero eso que el profeta dice sobre la reconciliación que nos produjo, sobre la expiación de los pecados y sobre la supresión de nuestra maldición, este corrupto lo retuerce refiriéndolo a Ciro, en cuya muerte los judíos vieron el castigo de sus propios crímenes ${ }^{55}$.

Es de destacar que en un proceso tan largo y minucioso las referencias a las anotaciones a la Biblia de Pagnino sean tan escasas, y debe reseñarse el hecho de que Servet se atribuya solamente la autoría de algunas de esas notas, en coincidencia con lo que escribiera en el prólogo a esa Biblia ${ }^{56}$.

Las acusaciones sobre los capítulos 7 y 8 de Isaías tienen de cierto el haber sido objeto de notas censuradas, pero yerran al referirlas a Ciro, ya que en esos capítulos Servet las relaciona literalmente con Abías, madre de Ezequías ${ }^{57}$.

53 A. Alcalá, Proceso de Ginebra, pág. 8

54 A. Alcalá, Proceso de Ginebra, págs. 15-16.

55 A. Alcalá, Proceso de Ginebra, págs. 79-80.

${ }^{56}$ Cf. pág. 290 de este trabajo.

${ }^{57}$ Cf. pág. 304 de este trabajo. 
En cuanto a Isaías 53 se refiere, ya vimos cómo la nota había sido censurada sólo parcialmente por su interpretación histórica referida a Ciro, mientras que quedaba intacta la interpretación cristológica ${ }^{58}$.

Por último, una breve reflexión sobre los quebrantos similares que, en personalidades tan distintas como las de Miguel Servet y Alonso Gudiel, pudieron producir las cárceles de la inquisición. Gudiel fue un hombre humilde, conciliador, discreto y melancólico ${ }^{59}$; Servet, un ser altivo, combativo, orgulloso, que no rehuía, sino que incluso buscaba, la confrontación. Las cárceles inquisitoriales los hermanaron en humillación y sufrimiento. Una frase de cada uno de ellos: Gudiel, quien al final de su proceso, enfermo, rompe en sollozos y suplica «que no le den más tormento, por amor de Dios, y por estar muy fatigado» ${ }^{60}$; Servet, en petición autógrafa a la Señoría de Ginebra de 10 de octubre de 1553: «el frío me atormenta grandemente a causa de mi cólico y mi hernia, lo cual me produce otras miserias que me da vergüenza escribiros» ${ }^{61}$.

La inquisición acabó con la humildad del uno y la soberbia del otro: por consunción en el caso de Gudiel; por el fuego en el caso de Servet.

\section{EL HEBREO DE SERVET}

Para contrastar los conocimientos que pudiera tener Servet de la lengua hebrea, hemos colacionado el texto de las notas a la edición de Pagnino (1542) con las palabras o frases hebreas que se encuentran en su De Trinitatis erroribus (1531) ${ }^{62}$ y su Christianismi restitutio $(1553){ }^{63}$, y estudiado algunas de las palabras hebreas que apa-

\footnotetext{
${ }^{58}$ Cf. pág. 307 de este trabajo.

59 Cf. E. Fernández Tejero y N. Fernández Marcos, «Alonso Gudiel: ciencia y miseria», en Homenaje a G. Morocho [en prensa].

${ }^{60}$ M. DE la Pinta Llorente, Causa criminal contra el biblista Alonso Gudiel. Catedrático de la Universidad de Osuna. Edición y estudio por - (Madrid 1942) pág. 189.

61 A. Alcalá, Proceso de Ginebra, pág. 90.

${ }^{62}$ De Trinitatis erroribus libri septem. Per Michaelem Serueto, alias Reues ab Aragonia Hispanum [Hagenau]. Anno M. D. XXXI.

${ }^{63}$ Christianismi restitutio... [Vienne] M. D. LIII.
} 
recen en las dos obras citadas y que no tienen eco alguno en las notas a Pagnino.

Son escasos en las notas a Pagnino los ecos de las dos obras fundamentales. La mayoría de las citas bíblicas en estas obras no tienen correspondecia con las notas marginales a la Biblia de Pagnino. Sí tienen en común el ser, casi en su totalidad, notas de carácter exegético, que no filológico, con un tono más atemperado en las notas a Pagnino que en las obras escritas por Servet mismo. En las notas a la edición de Pagnino no aparece la virulencia polémica de sus obras doctrinales.

Por ejemplo, en Christianismi restitutio, a propósito de Isaías 13,21-22, aplica los distintos nombres de las bestias que cita el profeta a los monjes y prelados de la Iglesia católica. En cambio, la nota a la Biblia de Pagnino en este pasaje es meramente explicativa: insulares bestiae in desolationibus silentiis seu viduatis domibus.

Sin embargo, no podemos ignorar que en algunos pasajes existe una cierta conexión entre las notas a Pagnino y las dos obras citadas de Servet. Algunos ejemplos:

- Salmo $110,1^{64}$ : contra la interpretación trinitaria del texto «dijo el Señor a mi Señor» (נאם יהוה לאדני), Servet arguye que en el original hebreo no son iguales los nombres divinos, sino que el primero es Yehoua y el segundo Adon; y añade: Praeterea iuxta veterem literalem seu historicum sensum, psalmus ille tribuitur Salomoni, quando est regnum in eum a viuente Davide translatum. I. parap. 29. En la nota marginal tachada a la edición de Pagnino falta la interpretación antitrinitaria, pero coincide en la atribución literal histórica del salmo a Salomón, y en la cita de 1 Paralipómenos 29.

- Isaías 7,14 ${ }^{65}$ : a propósito de ecce virgo, hay coincidencia absoluta con la nota marginal a Pagnino, como pasaje referido a Abías, madre de Ezequías.

\footnotetext{
${ }^{64}$ Pág. 65 de Christianismi restitutio.

${ }^{65}$ Págs. 69-70 de Christianismi restitutio.
} 
- Isaías 7,22: la nota marginal a Pagnino butyrum enim et mel comedet: id est magna erit fertilitas et veluti parvulis cibum ille dulcescet: cibus enim ille est parvulorum et fertilitatem arguet coincide con la explicación del pasaje en págs. 69-71 de Christianismi restitutio: est enim cibus ille puerorum... Ac etiam fertilitatem arguit ${ }^{66}$.

- Salmo 110,3: en la pág. 68 del Christianismi restitutio reproduce el texto hebreo, que traduce de la forma siguiente: Populus tuus spontaneae oblationes in die fortitudinis tuae, in pulchritudinibus sanctitatis, ab vtero, a diluculo: tibi ros adolescentiae tuae; y añade: ita hebraice punctuatur, et est verus sensus. En el texto hebreo de Christianismi restitutio se señala claramente el acento 'atnah tras la palabra משחר. En la nota correspondiente a la edición de Pagnino podemos leer: Secundum accentum dicuntur illi in magnificentia sanctitatis munera ibi dedisse ab utero et a diluculo, id est, et pueri ab utero, et ab ineunte die dona tibi sponte offerebant... quasi ros perfundens adolescentiam suam. Hay, pues, coincidencia en la mención del acento hebreo disyuntivo, en el vocabulario y en la interpretración. Pagnino, en su traducción, hace la pausa mayor tras sanctitatis: Populus tuus sponte veniet in die fortitudinis tuae, in puchritudinibus sanctitatis: ex utero ab aurora fuit tibi ros natiuitatis tuae.

Este ejemplo ilumina dos puntos importantes respecto al hebreo de Servet: la mención del acento disyuntivo hebreo, que utiliza para dar el sentido más correcto, y la traducción del original, más literal que la de Pagnino y que la de Vulgata, tanto iuxta Hebraeos como iuxta LXX.

La desproporción existente entre el material de las notas y el hebreo que puede estudiarse en las dos obras mencionadas de Servet es abrumadora. La comparación exhaustiva sólo nos ha permitido de-

${ }^{66}$ La nota de la edición de Restitución del cristianismo de A. Alcalá (pág. 212, nota 85) hace depender esta explicación del Comentario a los Profetas de D. Qimhî; en este comentario aparecen las palabras hebreas 'leche', 'manteca', 'miel' y 'abundancia', que figuran en el texto hebreo, pero no hay alusión alguna a 'niños'. 
tectar cuatro casos, todos ellos con eco en su Christianismi restitutio, publicada once años más tarde (1553) que las notas a la edición de Pagnino; no hay eco alguno en su De Trinitatis erroribus, publicada once años antes (1531).

Las palabras hebreas incluidas en estas dos obras no van más allá de los conocimientos básicos de un humanista del siglo XVI; no son notas filológicas, sino menciones de palabras hebreas comunes y conocidas, para avalar interpretaciones de carácter exegético en los problemas más debatidos del texto bíblico. Tampoco hay contraste entre el original y las distintas versiones, y en las menciones del Targum utiliza un texto casi irreconocible con el de las ediciones al uso ${ }^{67}$.

Estos recursos al hebreo se enmarcan más en la literatura de controversia que en los finos análisis filológicos que utilizaron otros humanistas como Luis de León y, especialmente, Arias Montano. Más parecen un intento de dárselas de conocedor del texto original que un auténtico interés por debatir problemas textuales. Se trata de un reducido vocabulario hebreo utilizado únicamente como aval de sus interpretaciones exegéticas.

Cualquier humanista estaría familiarizado con términos tan usuales como ישב, דבר, תמונה, ,עולם ,נדב,נדר, הלך, שמים, רוח, נאם יהוה, משיח,

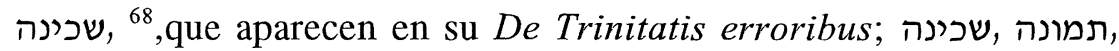
ישראל, ים, ,חשב, אמן, חיה, שאל ,רקיע, שמים, ,עשה, ,עמד, דבר ,דמות, ,צלם, נחם, תמיד, קדש, que aparecen en su Christianismi restitutio ${ }^{69}$.

${ }^{67}$ Ya advirtió J. FrIEDMAN, «Michael Servetus: the Case for a Jewish Christianity», Sixteenth Century Journal 4/1 (April 1973) págs. 87-110: pág. 103 que «There is hardly a single place where Servetus exhibited a true understanding of the source being used, or what problems had motivated the opinion of those rabbis whose views he found so congenial».

${ }^{68}$ Mesías, oráculo de Yahweh, viento, cielos, ir, hacer votos, ofrecer, eternidad, ofrenda, palabra, morar, morada.

69 Palabras escasas, muy comunes y que se encuentran en ambas obras: morada, ofrenda, imagen, semejanza, palabra, estar en pie, hacer, cielos, firmamento, morada de los muertos, vivir, ser fiel, pensar, día, Israel, santo, siempre, compadecerse. Es de agraceder que en las ediciones latinas del XVI apenas hay erratas en la grafía de las palabras hebreas, por contraste con las ediciones del siglo $\mathrm{XX}$. 
En ambas obras Servet dedica varias páginas a comentar los distintos nombres de Dios en hebreo (שלה), אלים , אלהים ,אל , אדני (שוה), שדי con recurso a etimologías populares y como apoyo a sus argumentos antitrinitarios: יהוה sólo puede aplicarse a Dios, mientras que a Cristo puede aplicársele el término ${ }^{70}$.

Las interpretaciones de los nombres divinos son un topos entre los exegetas del siglo XVI; Arias Montano lo trató extensamente en De arcano sermone y Luis de León en De los nombres de Cristo ${ }^{71}$.

El transfondo, el interés, las metas de las notas marginales a la Biblia de Pagnino y de las dos obras citadas de Servet son totalmente diferentes; responden a objetivos muy distintos, hasta el punto de parecer que ni siquiera son obra del mismo autor. ¿Paradojas de la personalidad contradictoria de Miguel Servet? ¿Quiso proteger la difusión de su edición de la Biblia de Pagnino, evitando manifestar su ideología en las notas, por miedo a que la inquisición prohibiera la difusión de la obra? ¿Recibió consignas del editor que, de no haber sido aceptadas, hubieran puesto en peligro la escasa retribución económica ${ }^{72}$ como corrector de pruebas en la casa de los Trechsel en Lyon?

Finalmente, si fue Servet quien incluyó las notas marginales a Pagnino, quizá no fue el autor de todas ellas, como afirma en el Proceso de Ginebra, sino sólo de algunas, y se limitó a editar las heredadas de los papeles de Pagnino mismo.

\footnotetext{
${ }^{70}$ Cf. De Trinitatis erroribus, pág. 20b. Según J. FrIEDMAN, «Michael Servetus: Exegete of Divine History», Church History 4 (1973) págs. 460-469, págs. $402-$ 403, los distintos nombres de Dios, en hebreo, son para Servet la clave para entender la naturaleza de la divinidad en un sistema de revelación progresiva.

${ }^{71}$ Cf. N. FERnÁndez MARCos, «De los nombres de Cristo de Luis de León y De arcano sermone de Arias Montano» y «El tratado De arcano sermone de Arias Montano», en N. Fernández Marcos y E. Fernández Tejero, Biblia $y$ Humanismo. Textos, talantes y controversias del siglo XVI español (Madrid 1997) págs. 133-152 y 177-184.

72 Cf. A. Alcalá Restitución del cristianismo, pág. 21.
} 


\section{PAGNiNO, EDITADO Y CORREGIDO POR ARIAS MONTANO}

Arias Montano intentó imprimir la Biblia de Pagnino como columna latina de la Biblia Regia (Amberes 1569-1573), pero Felipe II, aconsejado por los teólogos de Alcalá, no permitió que se prescindiera de la Vulgata.

Sin embargo, Arias Montano consiguió recuperar el texto de Pagnino e imprimirlo en un volumen del Apparatus como traducción interlineal de la Biblia hebrea. Cotejó el texto latino de Pagnino con el original hebreo, imprimió en letra cursiva sus correcciones a ese texto latino, y editó al margen, en redonda, el latín de Pagnino objeto de enmienda.

En el Nuevo Testamento del Apparatus editó como texto latino interlineal no el de Pagnino, sino el de la Vulgata, que corrigió con el mismo procedimiento utilizado en el Antiguo Testamento para Pagnino.

En los libros del Antiguo Testamento escritos en griego editó como traducción latina interlineal la misma versión interlineal de la Biblia Políglota Complutense a esos libros, sin corrección alguna ${ }^{73}$.

En el Prólogo al Antiguo Testamento hebreo elogió la utilidad de su traducción interlineal, puesto que la de Pagnino podía ser mejorada; y comparó su propia edición con una partitura musical, por cuanto podían leerse, con un solo golpe de vista, texto y música en el caso de las partituras, hebreo y latín en el caso de su traducción ${ }^{74}$.

El carácter herético de las teorías de Servet contagió su edición de la Biblia de Pagnino. De alguna manera, al incorporarla Arias Mon-

\footnotetext{
${ }^{73}$ Cf. Prefacio a la edición del Nuevo Testamento con traducción latina interlineal del Apparatus.

${ }^{74}$ plerisque in locis Pagnini interpretationem neque cohaerere cum veritate Hebraica, neque satis etiam cum Catholicae fidei mysteriis convenire... ad similitudinem eorum qui musicas cantilenas suis notis distinctas, iisque subiectas, et annexas uno aspectu canunt, hic simul Hebraea et Latina, uno etiam aspectu legi, ac simul conferri possint (Prólogo al Antiguo Testamento hebreo, Amberes 1571 , fols. $3 \mathrm{~b}$ y $4 \mathrm{~b})$.
} 
tano a la Biblia Regia devolvió a la traducción de Pagnino su prestigio original, aunque hubo de justificar su decisión en las reflexiones que siguen al Prólogo del Apparatus ${ }^{75}$. En esas reflexiones analizó algunos pasajes en los que ofrecía su propia traducción, y la defendió frente a los textos de Vulgata y Pagnino.

Para valorar las aportaciones de Arias Montano nos ha parecido ilustrativo estudiar un texto concreto, entre los muchos posibles, en el que se ponen de manifiesto los conocimientos filológicos de Arias Montano: el capítulo 66 del libro de Isaías.

Presentamos el texto hebreo de la Políglota, la traducción de Pagnino (1528), la edición del texto de Pagnino anotada por Servet (1542) y la edición del texto de Pagnino con las correciones que realizó Arias Montano en la Biblia Regia (1571) ${ }^{76}$.

- Isaías 66,2:

ואל זה אביט אל עני :Hebreo

Pagnino: Et cum toto hoc ad affictum ipsum ego potius specto ${ }^{77}$;

Arias Montano: Et ad illud respiciam ad afflictum.

- Isaías 66,3:

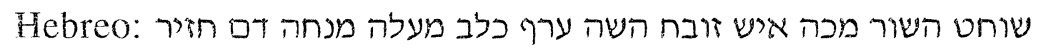

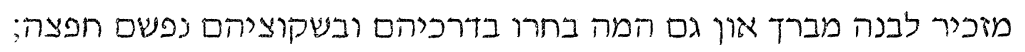

Pagnino: Qui imolat bovem est ac si interfecisset ${ }^{78}$ virum, qui

\footnotetext{
75 «Benedicti Ariae Montani de varia hebraicorum librorum scriptione et lectione commentatio», fechado en 1581.

${ }^{76}$ Ediciones designadas, por simplificar, como Pagnino, Servet y Arias Montano. Como hiciera este último, presentamos el texto latino de Pagnino, que Arias Montano editó al margen, en redonda, y, las correcciones que Arias Montano introdujo en el cuerpo del texto, en cursiva.

${ }^{77}$ El texto de Pagnino coincide en las tres ediciones; en adelante, tan sólo señalamos en nota las discrepancias entre ellas.

${ }^{78}$ Servet y Arias Montano: interficeret.
} 
imolat pecus, perinde est ac si decervicasset ${ }^{79}$ canem, qui offert oblationem est ac si offerret sanguinem suillum, qui suffire facit thus est ac si benediceret idolo, etiam haec elegerunt in viis suis, et abominationibus suis anima eorum delectata est;

Arias Montano: Mactans bovem percutiens virum: inmolans agnum decervicans canem: ascendere faciens munus sanguinem porci; memorans thus benedicens vanitati: etiam haec elegerunt in viis suis, et in contaminationibus suis anima eorum voluit.

- Isaías 66,4:

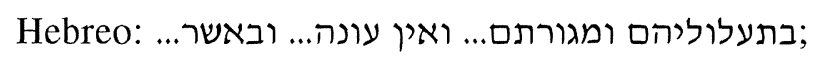

Pagnino: illusiones eorum, et quae timent... et non erat qui responderet... et quae...;

Arias Montano: in adinventionibus eorum timores eorum et non respondens... et in quo....

- Isaías 66,5:

Hebreo: החרדים... מנדיכם... יכבד;

Pagnino: qui tremitis... abominantes... glorificet;

Arias Montano: contremiscentes... elongantes... sit gloriosus.

- Isaías 66,7:

Hebreo: והמליטה;

Pagnino: peperit;

Arias Montano: enixa est.

- Isaías 66,8:

Hebreo: כזאת... כאלה...

Pagnino: simile ${ }^{80} \ldots$ similia ${ }^{81} \ldots$ parturiuit;

Arias Montano: sicut hoc... sicut haec... fuit aegra.

\footnotetext{
${ }^{79}$ Servet y Arias Montano: decervicaret.

80 Servet y Arias Montano: tale.

${ }^{81}$ Servet y Arias Montano: huic similia.
} 
- Isaías 66,9:

Hebreo: האני אשביר... המוליד ועצרתי;

Pagnino: num mulierem venire faciam ad partum... qui generare facio ero prohibitus;

Arias Montano: num ego matricem frangam... generare faciens et claudar.

- Isaías 66,10:

Hebreo: אהביה... המתאבלים;

Pagnino: qui diligitis eam... qui lugetis;

Arias Montano: diligentes eam... lugentes.

- Isaías 66,11:

Hebreo: מזוז;

Pagnino: propter splendorem;

Arias Montano: a splendore.

- Isaías 66,12:

Hebreo: נוטה... תשעשעו;

Pagnino: declino... risu afficiemini;

Arias Montano: declinans... oblectabimini.

- Isaías 66,13:

Hebreo: תנחמנו;

Pagnino: consolatur;

Arias Montano: consolabitur eum.

- Isaías 66,14:

Hebreo: את עבדיו וזעם;

Pagnino: a servis suis ${ }^{82}$ et irascetur;

Arias Montano: cum servis suis et indignabitur.

${ }^{82}$ Servet y Arias Montano: erga servos suos 
- Isaías 66,15:

Hebreo: אפו... בלהבי;

Pagnino: furorem suum... flamma;

Arias Montano: nasum suum... flammis.

- Isaías 66,16:

Hebreo: נשפט... חללי יהוה;

Pagnino: iudicat ${ }^{83}$... interfecti a domino;

Arias Montano: iudicio contendens... vulnerati Domini.

- Isaías 66,17:

Hebreo: המתקדשים והמטהרים... אחד בתוך... החזיר... יספו;

Pagnino: Qui sanctificant se et qui mundant se ${ }^{84} \ldots$ piscinam peculiarem existentem ${ }^{85}$ in medio horti ${ }^{86} \ldots$ suillam... consument ${ }^{87}$;

Arias Montano: Sanctificantes se et purificantes se... unam in medio... porci... finientur.

- Isaías 66,18:

Hebreo: ואנכי מעשיהם... באה לקבץ;

Pagnino: Ego autem ero cum operibus eorum ${ }^{88} \ldots$ Quando veniet tempus, veniet ${ }^{89}$, ut congreget ${ }^{90}$;

Arias Montano: Et ego opera eorum ${ }^{91} \ldots$ veniens ad congregandum.

${ }^{83}$ Servet y Arias Montano: iudicabit

${ }^{84}$ Servet y Arias Montano: qui purificant se.

${ }^{85}$ Servet y Arias Montano: de estas tres palabras sólo mantienen peculiarem.

${ }^{86}$ Falta esta palabra en Servet y Arias Montano.

87 Servet y Arias Montano: consumentur.

${ }^{88}$ Servet y Arias Montano: ego visitabo opera eorum.

${ }^{89}$ Servet y Arias Montano, omiten.

${ }^{90}$ Servet y Arias Montano: congregem.

91 Arias Montano omite en texto el visitabo de Servet porque falta el verbo en hebreo. 
- Isaías 66,19:

Hebreo: פליטים;

Pagnino: evasores ${ }^{92}$;

Arias Montano: evasos.

- Isaías 66,20:

Hebreo: מנחה... וברכב... ובכרכרות... קדשי;

Pagnino: donum... in quadrigis... et in carrucis... sanctum meum;

Arias Montano: munus... in curru... et in animalibus velocibus... sanctitatis meae.

- Isaías 66,22:

Hebreo: אני עשה עמדים לפני;

Pagnino: ego facio stant coram me;

Arias Montano: ego faciens stantes ad facies meas.

- Isaías 66,23:

Hebreo: מדי חדש בחדשו... ומדי שבת... להשתחות לפני;

Pagnino: de mense in mensem eius... et de sabbato... ut incurvet se coram me;

Arias Montano: a tempore mensis in mense eius... et de tempore sabbathi... ad incurvandum se ad facies meas.

- Isaías 66,24:

Hebreo: בפגרי... דראון;

Pagnino: cadavera... opprobrium;

Arias Montano: in cadavera... nausea.

De estos ejemplos pueden extraerse las conclusiones siguientes:

Arias Montano editó un texto de Pagnino prácticamente idéntico al que aparece en la edición de Servet. Cuando la edición de Pagni-

${ }^{92}$ Servet y Arias Montano: qui evaserint. 
no discrepa del texto de la edición de Servet, el Pagnino de Arias Montano coincide con el de la edición de Servet ${ }^{93}$. No hay caso alguno en el que la edición de Arias Montano coincida con la de Pagnino contra la de Servet.

La literalidad de la traducción del hebreo de Arias Montano es muy superior a la de la edición de Pagnino: respeta los participios hebreos, frente a las formas personales de Pagnino ${ }^{94}$; traduce las preposiciones hebreas con mayor literalidad ${ }^{95}$; refleja matices especiales de las formas verbales hebreas ${ }^{96}$; conserva el orden sintáctico hebreo, con perjuicio incluso de la comprensión de la frase latina ${ }^{97}$; llega a omitir el verbo cuando falta en hebreo ${ }^{98}$; hay casos de léxico en los que mantiene el idiotismo hebreo frente a la traducción explicativa ${ }^{99}$; tuvo incluso en cuenta el fenómeno hebreo del kěțîb/qěrê, consignado con la correspondiente nota marginal ${ }^{100}$.

\section{Los MÁRgenes de ARIAS Montano y los MÁrgENES DE SERVET}

Colacionando las notas marginales de Servet y las de Arias Montano al cap. 66 de Isaías, se comprueba que los márgenes de una y otra edición son de carácter distinto.

El contenido de las correciones textuales de Arias Montano a Pagnino responde a dos tipos de interés:

\footnotetext{
${ }^{93}$ Cf. Is 66,3 (dos casos); 66,8 (dos casos); 66,14; 66,16; 66,17 (cuatro casos) y 66,18 .

${ }^{94}$ Cf. Isaías 66,$3 ; 66,5 ; 66,10 ; 66,12 ; 66,16 ; 66,17$ y $66,22$.

${ }^{95}$ Cf. Isaías 66,4; 66,11 y 66,23.

${ }^{96}$ Como el hif ${ }^{\natural} l$; cf. Isaías 66,7 .

${ }^{97}$ Cf. Isaías 66,9; 66,17 y 66,20.

${ }^{98}$ Cf. Isaías 66,18.

${ }^{99}$ Cf. Isaías 66,15: 'nariz', frente a 'furor'.

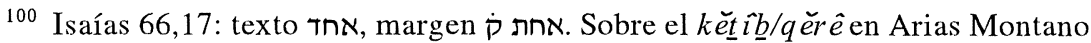
cf. E. Fernández Tejero, «Benedicti Ariae Montani de Mazzoreth ratione atque vsv», en VIII Congress of the International Organization for Masoretic Studies, ed. E. J. Revell (Chicago 1990) págs. 65-70 y M. T. OrTEGA MonAsterio, «Ariae Montani List of Ketib-Qere-Yattir Readings», en IX Congress of the International Organization for Masoretic Studies, ed. A. DotAN (s. 1. 1992) págs. 71-84.
} 
Traducir el original hebreo con mayor literalidad de lo que lo hiciera Pagnino, insertándolo en cursiva en el cuerpo del texto, e indicando al margen, en redonda, el original de Pagnino; ese reflejo estricto del original hebreo le llevó a recoger, también en los márgenes, fenómenos tan específicos como el del kěțîblqeerê.

Interés pedagógico, propio de las Políglotas españolas, que se manifiesta al indicar, siempre al margen, las raíces hebreas de las formas que podrían resultar especialmente difíciles.

Las notas de Servet al capítulo 66 de Isaías son siete:

Isaías 66,3: Haec est ultima ratio improbationis lapidei templi. Non solum enim praedictis rationibus in spiritu erit verum dei templum sed etiam hac quadam abominationem in isto vos faciatis;

Isaías 66,5: Gravis erit dominus si templum iterum dilaceret;

Isaías 66,6: Calamitas templi secundi ubi antequam nascerentur in christo, abortivi per Antiochum facti sunt. Innumera deinde multitudo est repente Christo nata celesti generatione. Quae omnia docet Zacharias;

Isaías 66,9: A la expresión ero prohibitus de Pagnino anota Servet: Ero conclusus ut mihi filios non generem;

Isaías 66,16: unus post unum in medio, id est, tres ordine siti. quibus conferuntur porcus abominatio et mus;

Isaías 66,21: erit exuberantia mensis in mense suo et exuberantia sabbati in sabbato suo, id est, tanta erit redundantia ut non solum anno nec mensi nec diei cuiusuis quid desit;

Isaías 66,23: frente al opprobrium de Pagnino, Servet anota nausea, en coincidencia con Arias Montano.

Con una sola excepción (Isaías 66,23), estas notas no son de carácter filológico. Las tres primeras son explicaciones exegéticas en torno a los sacrificios del Segundo Templo y del nuevo templo espiritual representado por Cristo y sus seguidores; las otras dos son interpretaciones parafrásticas de pasajes difíciles. 
En resumen: Servet anotó la Biblia de Pagnino, a lo sumo, como exegeta; Arias Montano, exclusivamente, como filólogo.

\section{CONCLUSIONES}

1. La traducción de Pagnino fue tan innovadora en el siglo XVI como lo fuera la de Jerónimo a finales del siglo IV. Nació en un ambiente de desconfianza, por dar prioridad al texto utilizado por los judíos; creció a la sombra de un hereje, por ser reeditada y anotada por Servet; y se salvó del olvido gracias al empeño filológico de Arias Montano, quien, al menos, logró incluirla como traducción interlineal del hebreo en el volumen del Apparatus.

2. No sabemos cuál fue exactamente el papel desempeñado por Servet en la reedición de la Biblia de Pagnino. El hecho es que en esta edición aparecen encabezamientos ausentes en la Biblia de Pagnino, y notas de autoría discutible. Encabezamientos y notas responden al carácter intocable del texto bíblico en sí mismo; sólo esas adiciones extratextuales permitían aclaraciones e interpretaciones válidas para los lectores cristianos. En la edición de Servet, los encabezamientos al libro de Isaías son cristianizantes, hasta convertir los diversos capítulos en profecías mesiánicas del Nuevo Testamento. Por el contrario, en el libro de los Salmos prevalece la interpretación histórica, que los relaciona con la vida de David, tal y como se describe en los libros de los Reyes.

En cuanto a los encabezamientos tachados, son, en su mayoría, interpretaciones de carácter histórico y literal. La censura inquisitorial no admitió asociar a Salomón o a Ezequías con los pasajes aplicados a Cristo en el Nuevo Testamento, pese a que se reconociera en algunos de ellos un sentido espiritual o tipológico referido a Cristo.

Las notas tachadas en el ejemplar de la Biblioteca Nacional de Madrid ponen de manifiesto las preocupaciones de los censores inquisitoriales hispanos. Estas preocupaciones son similares a las que se esgrimieron en los procesos inquisitoriales contra los hebraístas españoles del siglo XVI: las acusaciones no tuvieron una base filo- 
lógica; lo que no se toleraba era la exégesis literal histórica, que aplicaba pasajes del Antiguo Testamento a personajes determinados de la historia de Israel, y que habían sido atribuidos a Cristo en el Nuevo.

3. La colación de las notas de la Biblia de Pagnino con las palabras o frases hebreas que figuran en las obras teológicas de Servet plantea enigmas de difícil resolución. Apenas hay ecos de las unas en las otras.

De las obras doctrinales de Servet no se desprende el que fuera un verdadero hebraísta; el talante y las metas de esas obras son muy diferentes al que reflejan las notas, hasta el punto de parecer obra de distintos autores. Avala esta tesis el hecho de que, en el proceso de Ginebra, Servet se confesara autor de una parte de esas notas; el que en el Prólogo a la Biblia de Pagnino reconociera haber recibido un ejemplar ya corregido y anotado de dicha Biblia; el que las notas a la Biblia de Pagnino carezcan de la virulencia de sus obras doctrinales, y el que la desproporción entre el material de las notas y el hebreo que figura en sus obras teológicas sea abrumadora.

4. Arias Montano recuperó el texto de Pagnino y logró imprimirlo en el volumen del Apparatus, como traducción interlineal de la Biblia hebrea que él mismo corrigió, en busca de una literalidad mayor.

De la colación del capítulo 66 de Isaías se desprende que Arias Montano editó un texto de Pagnino prácticamente idéntico al que figura en la edición de Servet.

La literalidad de la traducción del hebreo al latín de Arias Montano es muy superior a la de la edición de Pagnino.

5. Servet no puede ser calificado de biblista ni por las notas a la edición de Pagnino - fueran o no suyas-, ni por el prácticamente nulo interés filológico de sus obras teológicas. En sus escritos prevalecen los intereses exegéticos y de controversia.

6. No puede negarse, sin embargo, el que Servet se inserte en la corriente de exégesis histórica y literal, fenómeno, por otra parte, nada singular en el siglo XVI, que fue compartido por algunos exegetas de la época, como se desprende del carácter de las notas tachadas 
por la inquisición y por las aclaraciones historizantes al libro de los Salmos.

Es cierto que algunas de las anotaciones a la Biblia de Pagnino reflejan conocimientos del hebreo, puesto que su texto no está respaldado ni por la Vulgata ni por las versiones castellanas más antiguas, y parecen proceder de una comprensión directa del original; pero son tan escasas las notas filológicamente válidas en la Biblia de Pagnino y es tan elemental el hebreo utilizado por Servet en sus obras teológicas, que hacen dudar de que el redactor de las notas deba ser identificado con Servet mismo.

\section{RESUMEN}

Miguel Servet apenas es conocido como biblista. Sin embargo, se le atribuye la autoría de los cientos de notas marginales que acompañan a la edición de la Biblia de Pagnino, que publicó en Lyon en 1542. En este artículo se analiza el carácter de dichas notas, con estudio especial de las que fueron tachadas por censores inquisitoriales españoles en el ejemplar que se conserva en la Biblioteca Nacional de Madrid. Se discute la autoría de Servet y sus conocimientos de la lengua hebrea (a la luz de la comparación entre estas notas y el hebreo de sus obras teológicas). Se subraya, por contraste, el enorme valor filológico de la edición de Pagnino, corregida por Arias Montano y publicada en la Políglota de Amberes.

PALABRAS CLAVE: Filología bíblica, humanismo, Inquisición, exégesis.

\section{SUMMARY}

Miguel Servet is hardly known as a biblical scholar. Nevertheless, the marginal notes included in his edition of Pagninus's Bible (Lyon 1542) are commonly attributed to him. In this article the characteristics of such notes are analysed, giving especial attention to the notes erased by the Spanish Inquisition in the volume which is preserved at the Madrid National Library. Servet's authorship of these notes is discussed as well as his knowledge of the Hebrew language by means of a comparison between the notes themselves and the use of Hebrew in his theological works. In contrast, the enormous philological value of Pagninus's edition, corrected by Arias Montano and published in the Antwerp Polyglot, is emphasized.

KEYwords: Biblical Philology, humanism, Inquisition, exegesis. 